\title{
EVALUATION OF KNOWLEDGE SYNERGY COMPONENTS
}

\author{
Ilona Skačkauskienė, Denisa Hrušecká, Aušra Katinienė, \\ Martin Čepel
}

\section{Introduction}

The $21^{\text {st }}$ century is characterised by social transformations, as economic development relies on knowledge rather than labour force, natural resources or capital as before (Jankauskienè et al., 2012). Drucker (1980) and Strassmann (1989) were among the first ones to talk about the importance of information and knowledge expressed in words - it is one of the most important and special resources which, when in use, can bring significant benefits. Torres et al. (2012) state that knowledge facilitating competition and innovation is a key asset of any organisation. Senge (2006) emphasised that only open and learning organisations would be able to generate a higher added value, acquire a competitive advantage, deal with difficulties and improve their management processes, systematically and purposefully manage and create environment which was favourable to effective knowledge management processes and organisational objectives. Highlevel knowledge management also positively influences the innovation performance and leading roles in innovation which is evident from the share of patents in different world regions (Juřičková, 2014).

Urban and Joubert (2017) consider intellectual capital a very important value contributor to performance when studying the relationship between its three basic components: human, structural and relational capital. Results of their study showed the significance of structural and relational capital in terms of organisational structure, processes and values to leverage human capital and facilitate organisational learning. It also includes knowledge sharing that must be stimulated at the organisational level. Employees' willingness and motivation are crucial for knowledge sharing, which Brčić and Mihelič (2015) proved in their study focused on factors influencing knowledge sharing in a generationally diverse workforce. In the emerging network economy and knowledge society, organisations must be ready for complex knowledge dissemination and management processes. Back in 1998, Neef et al. defined knowledge management as the ability to collect and use what a person knows to create new goods and share effective methods of operation. Interaction between the theory of knowledge management and the practice of knowledge creation, sharing and application requires deep knowledge of knowledge management and understanding from every participant (Klafke et al., 2016).

Members of an organisation create synergy through knowledge dissemination, generating unique knowledge and thus facilitating the development of organisational knowledge potential and the creation of unique organisational culture. Managing organisational knowledge necessary for the creation of added value and the acquisition of a competitive advantage requires evaluating knowledge synergy and its components. The knowledge of organisation's employees is not subject to generally recognised methods. Some researchers (Meenu, Mikku, \& Shishodia, 2012; Moradmand, Datta, \& Oakley, 2013) evaluate knowledge of organisation's employees by competence analysis, others (Fink, 2005; Park, Lee, \& Kwon, 2010) - by expert evaluation. Matošková (2016) has carried out an overview of methods used for measuring knowledge at organizational, group and individual level based on content analyses of secondary sources. She identified the gap between the micro (user and system level) and macro (organizational level) level assessment studies which should be discussed more in detail by further researches. Moreover, factors and evaluation systems analysed in papers on knowledge management are disassociated from a person, i.e. models are 
usually created for analysing skills required for a particular job at data, process and knowledge levels.

The research aims at identifying knowledge synergy components and providing a method for the evaluation of employee's knowledge synergy and its components to have a rational and objective evaluation of employee's knowledge, relations among employees and organisational knowledge synergy. To this end, the following tasks have been set: (1) identifying knowledge synergy components and issues of evaluation; (2) presenting types of knowledge synergy relations and an evaluation formula for each of these relations; (3) specifying components of employee's knowledge and factors reflecting knowledge content and providing an evaluation formula for each component; and (4) providing a method for the evaluation of organisational knowledge synergy.

The research applies methods of analysis, synthesis, graph theory and combinatorics as well as a systematic approach.

\section{Knowledge Synergy Components and Issues of Evaluation}

The ability to learn and use acquired knowledge has played the most important role in the development of humanity so far (Kloudová \& Chwaszcz, 2011). One of the key sources of long-term competitiveness of an organisation in a modern dynamic society is knowledge potential or the ability to continuously create new knowledge required for performance (Morkvènas, 2010). Knowledge creation is the main stimulus in an organisation (Nonaka \&Takeuchi, 1995), while a long-term competitive advantage and profitability come from the knowledge used by an organisation (Desauza, 2003; Huang, Ye, \& Gao, 2012).

Many researchers (Wu \& Choi, 2004; Khan, 2009; Ketchen \& Hult, 2011; Fombelle, Jarvis, Ward, \& Ostrom, 2011; Cho, Shaw, \& Kwon, 2013) talk about benefits of knowledge synergy, but only a few decide to model and calculate it. Modern science has limited methods for the evaluation of knowledge synergy. Synergy as a component in an actual productivity formula was introduced by Steiner (1972). Smith and Farquhar (2000) and Smith (2001) presented a network power formula used for the calculation of knowledge processes in a network. Belohlavek (2007) described the essential characteristics and content of components of the index, but did not specify how to evaluate those components. Eikenberry (2007) claims that synergy brings exponentially varying benefits. However, the application of the formula proposed by this researcher is rather problematic when there is a big difference between people who get along and people who do not get along in an organisation. Bivainis and Morkvènas (2008) argue that synergy depends on the level of the system's organisation as it determines the organisation's ability to use synergy promotion measures in a complex manner. Morkvènas (2010) suggests three components for the calculation of synergy: a knowledge multiplier, the rate of effective relations and the average potential of employees' knowledge per relation. A closer look at formulas raises questions as to the logical sequence and purpose of their application, thus complicating calculations.

Analysis of sources of knowledge content and synergy formation has established that knowledge synergy components are relations among employees and employee's knowledge (Skačkauskienè \& Katinienè, 2015). The evaluation of knowledge synergy requires the identification of components of employee's knowledge and relations among employees (Skačkauskienè et al., 2017). Analysis of the content of relations among employees found that communication among employees may create one-way or two-way relations, and employee's knowledge consists of explicit and tacit knowledge (Fig. 1).

Employees use one-way communication to share both explicit and tacit knowledge. They share this knowledge in case of other types of communication, too. The types of relations were put in the following set of components: $X=\left\{X_{1}\right.$, $\left.x_{2}, x_{3}, x_{4}\right\}$, and employee's knowledge in the following set of components: $Y=\left\{y_{1}, y_{2}\right\}$. The set of knowledge synergy factor components will be as follows: $\left\{x_{1} y_{1}, x_{2} y_{1}, x_{3} y_{1}, x_{4} y_{1}, x_{1} y_{2}\right.$, $\left.x_{2} y_{2}, x_{3} y_{2}, x_{4} y_{2}\right\}$. The grouping of the set of knowledge synergy components and arithmetic operations results in the following: $X+Y=$ $=\mathrm{x}_{1} \mathrm{y}_{1}+\mathrm{x}_{2} \mathrm{y}_{1}+\mathrm{x}_{3} \mathrm{y}_{1}+\mathrm{x}_{4} \mathrm{y}_{1+} \mathrm{x}_{1} \mathrm{y}_{2+} \mathrm{x}_{2} \mathrm{y}_{2}+\mathrm{x}_{3} \mathrm{y}_{2}+\mathrm{x}_{4} \mathrm{y}_{2}=\mathrm{y}_{1}$ $\left(\mathrm{x}_{1}+\mathrm{x}_{2}+\mathrm{x}_{3}+\mathrm{x}_{4}\right)+\mathrm{y}_{2}\left(\mathrm{x}_{1+} \mathrm{x}_{2}+\mathrm{x}_{3}+\mathrm{x}_{4}\right)=\left(\mathrm{y}_{1}+\mathrm{y}_{2}\right)$ $\left(x_{1}+x_{2}+x_{3}+x_{4}\right)$.

Such distribution of the set of factors proves that knowledge multiplies, i.e. knowledge multiplies as many times as the person wants it to. Thus, after identifying knowledge synergy components and sets of factors as 


\section{Fig. 1: Fundamental diagram of the evaluation of knowledge synergy}

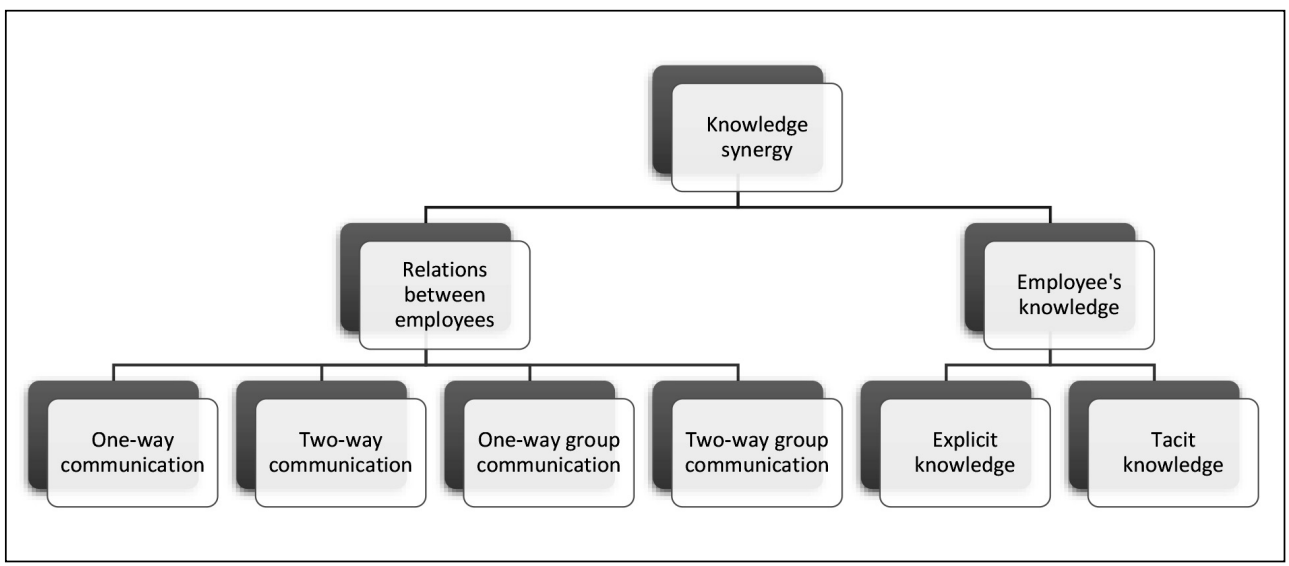

Source: Skačkauskienè et al. (2017)

well as analysing the methodological basis of the evaluation of knowledge synergy, the suggestion is to calculate knowledge synergy using the following formula:

$$
\mathrm{S}=\mathrm{R} \cdot \check{Z}
$$

where $S$ is knowledge synergy; $R$ is relations among employees; $Z$ is employee's knowledge.

Researchers of relations among employees (a knowledge synergy component) - Graičiūnas (1932), Urwick (1943), Simon (1947), Newman, Barabási and Duncan (2006), Bianchi (2010) indicate that an employee can effectively create a limited number of relations. If an employee creates many relations, some of them become ineffective.

Another knowledge synergy component employee's knowledge - is subject to different methods. Some studies evaluate employee's knowledge by competence analysis, others by expert evaluation. Moradmand, Datta and Oakley (2013) claim that knowledge evaluation models may be built on Bloom and Andersen's taxonomy (Lithuanian Qualifications System is also built on this taxonomy). There is no uniform approach to knowledge evaluation in terms of definitions (competence, qualification, skills, abilities, knowledge). The identified factors are adapted to a specific organisation, i.e. the lack of standards increases a gap between evaluation results (it is difficult to compare them).

\section{Empirical Findings and Calculation of Knowledge Synergy Components}

Evaluation of knowledge synergy is a very complex process that must consider both the employee's knowledge itself and the level of knowledge sharing. Based on the literature review, authors have established knowledge synergy as relations among employees and their knowledge (explicit and tacit). Consequently, individual types or relations and types of employee's knowledge were analysed more in detail in order to identify general relations and formulate mathematical formulas for their calculation which are presented in the following sections. Together 74 different research studies, researchers' comments and professionals' insights were used to identify the most relevant evaluation factors for measuring employee's knowledge. After that, the most frequent factors were included into the final formula for the evaluation of knowledge synergy. The presented knowledge synergy evaluation model is also normalised in order to be applicable in all relevant areas with different units of measure.

\subsection{Types of Communication and Calculation of Knowledge Sharing}

Knowledge synergy between employees may never form if they do not share knowledge. 


\section{Tab. 1: Suggestion for the calculation of synergy and types of communication}

\section{Simple synergy}

\begin{tabular}{|c|c|c|c|c|}
\hline $\begin{array}{l}\text { Type of } \\
\text { communication }\end{array}$ & \multicolumn{2}{|c|}{$\begin{array}{l}\text { One-way communication } \\
\text { (one with one) }\end{array}$} & \multicolumn{2}{|c|}{ Two-way communication (one with one) } \\
\hline Formula & $r_{1 \rightarrow 1}=\frac{n(n-1)}{2}$ & & $r_{1 \leftrightarrow 1}=n(n-1)$ & \\
\hline \multicolumn{5}{|c|}{ Complex synergy } \\
\hline $\begin{array}{l}\text { Type of } \\
\text { communication }\end{array}$ & $\begin{array}{l}\text { One-way group } \\
\text { communication } \\
\text { (one with many, } \\
\text { many with one) }\end{array}$ & $\begin{array}{l}\text { One-way group } \\
\text { communication } \\
\text { (many with } \\
\text { many) } \\
\end{array}$ & $\begin{array}{l}\text { Two-way group } \\
\text { communication (one } \\
\text { with many, many with } \\
\text { one) }\end{array}$ & $\begin{array}{l}\text { Two-way group } \\
\text { communication } \\
\text { (many with many) }\end{array}$ \\
\hline Formula & $r_{1 \rightarrow \infty}=n\left(\frac{2^{n}}{2}+1\right)$ & $r_{\infty \rightarrow \infty}=\prod_{n=1}^{m} r_{1 \rightarrow 1}$ & $r_{1 \leftrightarrow \infty}=2 n\left(\frac{2^{n}}{2}+1\right)$ & $r_{\infty \leftrightarrow \infty}=2 \prod_{n=1}^{m} r_{1 \leftrightarrow 1}$ \\
\hline
\end{tabular}

Note: $r$ is relations by type, $n$ is the number of group members, $m$ is the number of groups.

However, it definitely forms if knowledge is being shared. The following types of relations are possible when employees share knowledge:

- when one employee shares knowledge with another employee (one with one);

- when one employee shares knowledge with a group of employees (one with many);

- when a group of employees shares knowledge with a group of employees (many with many).

Based on the types of communication (Fig. 1) and methods for the calculation of effective relations, a respective formula is applicable for the calculation of synergy (Tab. 1).

The benefits of this proposal lie within the fact that relations of a person and a group can be calculated by a method based on the analysis of organisational structures, while relations of individual employees may be calculated by a management theory-based method. Such distinction between relations and the application of methods based on structural analysis and management theory allow for a full assessment of relations among employees, which is a component of knowledge synergy.

The final number of relations is calculated by adding all types of possible relations:

$$
R=\sum_{i=1} r_{i}
$$

where $i$ is the number of types of relations.

\subsection{Types of Knowledge and Their Evaluation}

According to Nonaka and Takeuchi (1995), the best way to evaluate employee's knowledge - another component of synergy - is to divide factors into two blocks: (1) explicit knowledge and (2) tacit knowledge. An employee uses knowledge at work in different volumes, therefore each block of knowledge should be distinguished by significance, i.e. explicit knowledge and tacit knowledge each have a coefficient of significance $\alpha$ and $\beta$. The following formula (3) is proposed for the calculation of employee's knowledge:

$$
\check{Z}=\alpha \sum_{j=1} V I_{j}+\beta \sum_{j=1} V N_{j}
$$

where $\check{Z}$ is employee's knowledge, $\alpha$ is the coefficient of significance of explicit knowledge, $\mathrm{VI}_{j}$ is factors of employee's explicit knowledge, $\beta$ is the coefficient of significance of tacit knowledge, $V N_{j}$ is factors of employee's tacit knowledge, $j$ is the number of employees.

Factors of employee's explicit and tacit knowledge are selected and evaluated by a number of methods. Cole (1993) introduced a work complexity evaluation system including 10 criteria. As the most important (weight $10 \%$ to $20 \%$ ) are considered: education, timely performance of 
tasks, work experience, personal responsibility for the job and its quality, participation in making management decisions, and team leadership. The remaining criteria of lower importance are: intensity of contacts within and outside the company, responsibility for information storage, and issues with work conditions. Some of them reflect the employee's personal input into work and the amount of tacit knowledge.

Šileika (2004) adapted the Geneva Scheme approved by the International Labour Organisation and developed a job evaluation methodology where factors are grouped by the following levels: education, professional experience, levels of duties and management, scale of decisions and freedom of action, autonomy and creativity at work, responsibility, complexity of work and work conditions. The number of levels depends on the specificity of a particular factor and the possibility of revealing its importance as fully and objectively as possible. The level of each factor is assessed in points. They are arranged by importance in an ascending order (for instance, the factor of education is divided into seven levels, where their value is based on job requirements for education; the factor of professional experience is divided into ten levels where their value is based on the importance of work experience, the ability to perform tasks of varying complexity and requiring continuous professional development, the ability to solve problems of different complexity, etc. for a particular job). Elements of the evaluation methodology may be adapted to the evaluation of employee's knowledge.

When analysing general job factors, Žaptorius (2007) identified work factors and introduced their assessment in points. For example, the complexity of work is evaluated based on the employee's education, professional experience, scope of decisions and levels of management and duties. The next work factors used by Žaptorius are: social value, responsibility and complexity of work and work conditions.

In the analysis of employee's knowledge potential, Morkvènas (2010) identified eleven factors: professional experience, education, level of duties, employee's salary, complexity of work, motivation, employee's influence on the realisation of organisational goals, use of technology, responsibility, work culture and autonomy at work. The researcher claims that all factors analysed by literature may influence employee's knowledge, but only some of them have real importance. Thus, he performed an experiment and identified three key factors based on expert evaluation, i.e. education, professional experience and level of duties.

When it comes to the evaluation of statutory officers, some researchers (Vanagas \& Tumènas, 2008) suggest different performance evaluation criteria for managers and other employees. Criteria for the evaluation of managers' performance include the implementation of organisation's strategic objectives, management and leadership, while employees' performance is evaluated based on productivity, competence and quality (Tab. 2).

The methodology (2010) developed by the European Social Fund Agency evaluates employees based on their job. A special questionnaire filled out by individual employees is used to discuss the achievement of last year's objectives, to learn about difficulties at work and demotivating factors, to consider employee's proposals as to how to achieve the set objectives better, to talk about objectives for the next year and how to achieve them, and to look at the educational needs. On one hand, the evaluation methods used by Vanagas and Tumènas and the European Social Fund Agency prevent subjectivity. On the other hand, the objectivity of evaluation is directly related to such conditions as comprehensibility and clarity of evaluation criteria for the one who is being evaluated and the evaluator, simple, clear and open evaluation procedures, and being a competent evaluator.

It should be noted that the methodology developed by Šileika et al. emphasises the need to separate evaluation of duties, which serves as a basis when grouping jobs (positions) into an appropriate number of categories by the complexity of work, from the evaluation of the effectiveness, professionalism and other qualities of an employee holding a specific job (position). The authors stress that a different evaluation system gives the possibility to group and classify jobs of different complexity (in a broad sense) by comparing them to each other and use it for establishing (basic) salary scales. However, when creating a knowledge factors evaluation system, it is important to distinguish the key factors that reflect knowledge of each employee, irrespective of their job.

Creating a system of factors is a difficult process. Based on the object of research or 
Criteria for the evaluation of managers' performance

\begin{tabular}{|c|c|c|}
\hline $\begin{array}{l}\text { Implementation of organisation's } \\
\text { strategic objectives }\end{array}$ & Management & Leadership \\
\hline $\begin{array}{l}\text { Perception of the organisation's } \\
\text { vision, mission, objectives, tasks } \\
\text { and values; prioritisation. } \\
\text { Organisation and coordination } \\
\text { of the development and } \\
\text { implementation of the } \\
\text { organisation's strategic plan. } \\
\text { Management of information related } \\
\text { to the organisation's activities } \\
\text { (collection, processing and } \\
\text { analysis of information, formulation } \\
\text { of conclusions, finding solutions } \\
\text { for the relevant issues, systematic } \\
\text { evaluation of issues and processes } \\
\text { in the organisation). } \\
\text { Ensuring control and } \\
\text { accountability. }\end{array}$ & $\begin{array}{l}\text { Personnel management. } \\
\text { Management of financial } \\
\text { resources. } \\
\text { Management of material } \\
\text { resources. } \\
\text { Technological management. }\end{array}$ & $\begin{array}{l}\text { Ensuring effective } \\
\text { communication and } \\
\text { cooperation in the } \\
\text { organisation, promotion of } \\
\text { interinstitutional cooperation. } \\
\text { Results orientation, influence } \\
\text { on subordinates' behaviour } \\
\text { and thinking. } \\
\text { Process and change } \\
\text { management (development, } \\
\text { management and improvement } \\
\text { of processes, optimisation } \\
\text { and assessment, innovation, } \\
\text { risk analysis, planning and } \\
\text { implementation of changes). } \\
\text { Representation of the } \\
\text { organisation. }\end{array}$ \\
\hline
\end{tabular}

Criteria for the evaluation of employees' performance

\begin{tabular}{|c|c|c|}
\hline Productivity & Competence & Performance quality \\
\hline $\begin{array}{l}\text { Achieved results and their } \\
\text { compliance with the objectives } \\
\text { established by the structural unit or } \\
\text { the organisation. } \\
\text { Performance of tasks of different } \\
\text { certainty and complexity. } \\
\text { Information management } \\
\text { (collection, processing and } \\
\text { analysis, formulation of } \\
\text { conclusions, finding solutions for } \\
\text { the relevant issues). } \\
\text { Work planning and organisation, } \\
\text { effective distribution of work time. } \\
\text { Communication and cooperation } \\
\text { (teamwork, institutional assistance, } \\
\text { attitude to clients). }\end{array}$ & $\begin{array}{l}\text { Use of available knowledge and } \\
\text { skills to achieve results. } \\
\text { Improvement of qualification. } \\
\text { Exercising the rights granted to } \\
\text { a civil servant and performance } \\
\text { of functions assigned to a civil } \\
\text { servant. } \\
\text { Good command of English and } \\
\text { French (or German) and ability } \\
\text { to represent Lithuania in the } \\
\text { European Union (applicable } \\
\text { to civil servants representing } \\
\text { Lithuania in the EU). } \\
\text { Personal motivation (pro- } \\
\text { activeness, creativity, pursuit of } \\
\text { innovation, tendency to develop } \\
\text { knowledge, professional activity). }\end{array}$ & $\begin{array}{l}\text { Tasks performed in a proper } \\
\text { and timely manner. } \\
\text { Performance based on the } \\
\text { quantity-quality ratio. } \\
\text { Compatibility of personal } \\
\text { goals (results, career, } \\
\text { innovation, personal } \\
\text { development goals) and } \\
\text { plans with the organisation's } \\
\text { objectives and plans and their } \\
\text { implementation. } \\
\text { Self-analysis. } \\
\text { Responsibility for performance. }\end{array}$ \\
\hline
\end{tabular}

Source: own based on Vanagas and Tumènas (2008)

the phenomenon analysed, researchers pick only factors that are suitable and important for that particular object. Thus, the number and content of the factors included depend on the qualification of both researchers and evaluators. In other words, the system includes only those factors that are deemed the most important by experts. At the same time, even this kind of system includes factors that have a mixed impact on the phenomenon analysed (Podvezko, 2008). 74 expert studies in total (research studies and professionals' comments) were deeply analysed in order to identify the most relevant factors for the knowledge synergy evaluation system. Different authors consider different factors to be the most important (see examples above), but some of them are repeated more often. This study is focused on the most 


\begin{tabular}{|c|c|c|c|c|c|}
\hline No & Factor & $\begin{array}{l}\text { Frequency } \\
\text { of use }\end{array}$ & Range & Subset & $\begin{array}{c}\text { Average } \\
\text { in the } \\
\text { range }\end{array}$ \\
\hline 1. & Education & 25 & [27-19] & $V_{A}$ & \multirow[t]{2}{*}{24.5} \\
\hline 2. & Use of technology & 24 & [27-19] & $V_{A}$ & \\
\hline 3. & Professional experience & 17 & {$[18-10]$} & $V_{B}$ & \multirow[t]{4}{*}{12.75} \\
\hline 4. & Motivation & 14 & {$[18-10]$} & $V_{B}$ & \\
\hline 5. & $\begin{array}{l}\text { Employee's influence on the realisation of } \\
\text { organisational goals }\end{array}$ & 10 & [18-10] & $V_{B}$ & \\
\hline 6. & Levels of duties and management & 10 & [18-10] & $V_{B}$ & \\
\hline 7. & Complexity of work & 9 & {$[9-1]$} & VC & \multirow[t]{21}{*}{3.19} \\
\hline 8. & Work culture & 9 & {$[9-1]$} & $V_{C}$ & \\
\hline 9. & Employee's salary & 8 & [9-1] & $V_{C}$ & \\
\hline 10. & Responsibility & 7 & [9-1] & $V_{C}$ & \\
\hline 11. & Autonomy at work & 7 & [9-1] & $V_{C}$ & \\
\hline 12. & Scale of decisions and freedom of action & 3 & [9-1] & $V_{C}$ & \\
\hline 13. & Issues with work conditions & 2 & [9-1] & $V_{C}$ & \\
\hline 14. & Responsibility for information storage & 2 & [9-1] & $V_{C}$ & \\
\hline 15. & Personal responsibility for the job and its quality & 2 & [9-1] & $V_{C}$ & \\
\hline 16. & Participation in making management decisions & 2 & [9-1] & $V_{C}$ & \\
\hline 17. & Timely performance of tasks, work planning & 2 & [9-1] & $V_{C}$ & \\
\hline 18. & Team leadership & 2 & [9-1] & $V_{C}$ & \\
\hline 19. & Improvement of qualification & 2 & {$[9-1]$} & $V_{C}$ & \\
\hline 20. & Personal criteria & 2 & [9-1] & $V_{C}$ & \\
\hline 21. & Work experience & 1 & [9-1] & $V_{C}$ & \\
\hline 22. & Intensity of contacts within the company & 1 & [9-1] & $V_{C}$ & \\
\hline 23. & Autonomy and creativity at work & 1 & [9-1] & $V_{C}$ & \\
\hline 24. & Intensity of contacts outside the company & 1 & {$[9-1]$} & $V_{C}$ & \\
\hline 25. & Social value & 1 & [9-1] & $V_{C}$ & \\
\hline 26. & Work conditions & 1 & [9-1] & $V_{C}$ & \\
\hline 27. & Communication and cooperation & 1 & {$[9-1]$} & $V_{C}$ & \\
\hline
\end{tabular}

frequently used factors which create the basis of our model. The system may have a limited number of factors. Too many factors make it impossible to have an accurate evaluation of a factor's impact on the final result. The analysis of knowledge factors results in a set of 27 knowledge evaluation factors ordered based on their frequency of use (Tab. 3).

There are more than 20 knowledge evaluation factors ( $\mathrm{i}>20$ ), therefore it is important to identify the most important ones. For this purpose, factors are grouped in subsets by their importance (Tab. 3). A set of initial knowledge factors $V=\left\{V_{1}, V_{2}, \ldots V i\right\}$ may be expressed in three subsets $V_{A}, V_{B}$ and $V_{C}$, based on their influence on the key objective the evaluation of knowledge synergy: $V_{A}$ is a subset of indicators with the greatest impact on knowledge synergy; $V_{B}$ is a subset of indicators with an average impact on knowledge synergy; 
$V_{C}$ is a subset of indicators with the lowest or no impact on knowledge synergy. The average of all factors has been calculated to establish range limits. The results are as follows: The frequency range of the $V A$ subset is [27-19], of $V B$ [18-10] and of $V C$ [9-1]. As indicators of the $V C$ subset are known, they can be eliminated from the $V$ set, thus identifying the key factors.

The more factors are included in the system, the more difficult it is to establish their significance. On the other hand, the phenomenon analysed is better represented (Joro \& Viitala, 1999; Ginevičius \& Podvezko, 2005). When the number of factors is relatively high, it is difficult to have a direct evaluation of factors and a consistent comparison of all factors (Podzviesko, 2008). When there are more than twelve factors, the expert cannot accurately determine the impact of relations among all pairs of factors (Ginevičius, 2006). This is why it is recommended to have no more than twelve factors in a factors evaluation system. Factors that are important for the evaluation of knowledge synergy fall into the set of knowledge evaluation factors from subsets $V_{A}$ and $V_{B}$. These two subsets include a total of only 6 factors. Therefore, also a part of subset $V C$ was included, specifically factors with the frequency range 9 to 7 : the complexity of work, work culture, employee's salary, and responsibility. The frequencies of these factors deviate from the average by 5.81 to 3.81 , and the standard deviation is 2.62 and 0.62 , respectively. It should be noted that frequencies of factors from subset $V C$ with the repetition rate from 9 to 7 deviate from the average of subset $V_{B}$ by 3.75 to 5.75 , respectively, and therefore they should be included in the set of knowledge evaluation factors. The factors
'Autonomy at Work' and 'Scale of Decisions and Freedom of Action' are overlapping and should be combined into one. The frequency of use of the combined factor 'Autonomy at Work' is 10 . It shows that this factor falls into the subset $V B$.

As mentioned above, the number of evaluation factors should not be higher than 12. Therefore, only the most frequent factors with the frequency of use higher than 6 are considered. This group includes 11 factors in total. However, the factor 'Professional Development' also has a significant impact on the employee's knowledge, competitiveness and work efficiency. Over the recent decades, the concept of qualification has been associated more with stages of shifts and developments in the professional training system. Qualification is a formal recognition of a person's suitability for a certain professional activity, based on the person's knowledge, abilities and values (Lobanova \& Chlivickas, 2009). Employees are competitive in an organisation only if they continuously improve their qualification, i.e. improve their personal knowledge and skills. Improvement of qualification must be included in the system for the evaluation of knowledge factors as an important factor with a significant impact on personal knowledge and the evaluation of knowledge content.

Having analysed metadata and identified the most important knowledge evaluation factors, it is appropriate to divide factors that affect employee's knowledge into two blocks: explicit knowledge and tacit knowledge (Tab. 4).

It is suggested to calculate explicit knowledge as follows:

$$
V I=\tilde{l} I+\tilde{t} T+\tilde{p} P+\tilde{l} L+\tilde{u} U+\tilde{k} K
$$

\section{Tab. 4: Factors affecting employees' knowledge}

\begin{tabular}{l|l} 
Explicit knowledge (coefficient $\boldsymbol{\alpha})$ & \multicolumn{1}{c}{ Tacit knowledge (coefficient $\boldsymbol{\beta}$ ) } \\
\hline Education $(\tilde{l})$ & Complexity of work $(\tilde{g})$ \\
\hline Use of technology at work $(\tilde{t})$ & Employee's influence on the realisation of organisational goals $(\tilde{o})$ \\
\hline Professional experience $(\tilde{p})$ & Work culture $(\tilde{d})$ \\
\hline Level of duties $(\tilde{l})$ & Responsibility $(\tilde{a})$ \\
\hline Employee's salary $(\tilde{u})$ & Motivation to work $(\tilde{m})$ \\
\hline Improvement of qualification $(\tilde{k})$ & Autonomy at work $(\tilde{s})$ \\
\hline
\end{tabular}


where $\mathrm{VI}$ is the estimate of explicit knowledge, $\tilde{l}$ is the coefficient of education, $I$ is the estimate of education, $\tilde{t}$ is the coefficient of the use of technology at work, $T$ is the value of the use of technology at work, $\tilde{p}$ is the coefficient of professional experience, $P$ is the value of professional experience, $\tilde{l}$ is the coefficient of the level of duties, $L$ is the value of the level of duties, $\tilde{u}$ is the coefficient of employee's salary, $U$ is the value of employee's salary, $\tilde{k}$ is the coefficient of the improvement of qualification, $K$ is the value of the improvement of qualification.

The formula proposed for the calculation of tacit knowledge is as follows:

$$
V N=\tilde{g} G+\widetilde{o} O+\widetilde{d} D+\widetilde{a} A+\widetilde{m} M+\widetilde{s} S
$$

where $V N$ is the estimate of tacit knowledge, $g$ is the coefficient of the complexity of work, $G$ is the value of the complexity of work, $\tilde{o}$ is the coefficient of employee's influence on the realisation of organisational goals, $O$ is the value of employee's influence on the realisation of organisational goals, $\tilde{d}$ is the coefficient of employee's culture, $D$ is the value of employee's culture, $\tilde{a}$ is the coefficient of responsibility, $A$ is the value of responsibility, $\tilde{m}$ is the coefficient of motivation, $M$ is the value of motivation, $\tilde{s}$ is the coefficient of autonomy at work, $S$ is the value of autonomy at work.

After specifying factors of explicit and tacit knowledge, the formula for the evaluation of employee's knowledge is as follows:

$$
\begin{aligned}
& \check{\mathrm{Z}}=\alpha(\tilde{l} I+\tilde{t} T+\tilde{p} P+\tilde{l} L+\tilde{u} U+\tilde{k} K)+ \\
& +\beta(\tilde{g} G+\tilde{o} O+\tilde{d} D+\tilde{a} A+\tilde{m} M+\tilde{s} S)
\end{aligned}
$$

Calculations of knowledge synergy components give a full assessment of employee's knowledge and relations among employees as well as reveal the content of employees' knowledge. Results of the evaluation of knowledge synergy may be used for adjusting relations among employees and knowledge sharing processes, also for changing or integrating new knowledge sharing and cooperation promotion measures.

\section{Evaluation of Knowledge Synergy}

The content of elements of a knowledge component - factors - must be normalised due to different units of measurement, e.g. experience is measured in years and salary in Euros. For the purpose of comparison, a normalisation requirement is used:

$$
\sum_{i=1}^{j} \widetilde{v}_{i}=1
$$

where $\widetilde{v}_{i}>0$ is normalised weights of criteria.

In case of most knowledge component factors, the best value is the highest value, therefore factors should be maximised, i.e. minimising factors should be reduced to maximising factors following this formula (Hwang \& Yoon, 1981; Ginevičius \& Podvezko, 2007; Podvezko, 2008):

$$
\widetilde{v}_{i}=\frac{\min v_{i}}{v_{i}}
$$

where $v_{i}$ is the value of the $\mathrm{i}^{\text {th }}$ factor; $\min v_{i}$ is the minimal value of the $i^{\text {th }}$ factor.

After normalising data using formula (8), the minimal (best) indicator value will be the highest value, which is 1 . Similarly, values of maximising factors may be converted so that the highest (best) value is the highest value.

To normalise relations among employees, a construct (9) is introduced - it helps to calculate the value of knowledge synergy correctly.

$$
r_{n o r m}=\frac{100}{R}
$$

where $r_{\text {norm }}$ is a normalised value of relations, $R$ is relations.

Formula (9) reflects the fact that coefficient $r_{\text {norm }}$ is reducing with the increasing number of relations $R$. It also confirms a statement that when the number of relations is increasing, relations become ineffective.

When formula (2) is integrated into formula (9), the final formula for the evaluation of knowledge synergy is as follows:

$$
S=\frac{\left(\alpha \sum_{j=1} V I_{j}+\beta \sum_{j=1} V N_{j}\right)}{\sum_{i=1} r_{i}} \cdot 100
$$

The examination of the factors of knowledge synergy in an organisation makes it possible 
to view, analyse and evaluate intermediate results. Analysis of every factor may be used for adjusting possibilities of the acquisition of knowledge, the improvement of qualification, learning, and career. When calculating results, intermediate results help to assess relations among employees, reveal specific features of cooperation, problem areas and knowledge sharing, which in turn allows for the adjustment of employees' performance and maybe even changes in the organisational structure of the organisation or its units and sound strategic decision-making. The evaluation of knowledge synergy makes an organisation more flexible, competitive, innovative, modern, learning, and creating higher added value. Undoubtedly, it gives more benefits to employees, the organisation and the country.

\section{Discussion}

It can be said, and many researches mentioned above confirm, that it is difficult to measure the level of employee's knowledge. In case of knowledge synergy, it is doubly difficult. The proposed approach to knowledge synergy evaluation considers both relations among employees and the level of employees' knowledge itself. It includes the most relevant components identified through the in-depth research. The problem of measuring intellectual capital and knowledge synergy is very much present nowadays, which is also confirmed by the latest Eurostat analysis (Eurostat, 2017a; Eurostat, 2017b). It is evident that employment in knowledge intensive sectors has been increasing since 2013 and in case of females employment, it has been slightly increasing even since 2010 (Fig. 2). With regard to the new trends, technological progress, or recently the fourth industrial revolution, the requirements on employees' knowledge will be rising during the following years.

In terms of education, an increasing number of secondary, post-secondary and tertiary educated people are being employed in knowledge intensive sectors. In case of less than primary, primary and lower secondary educated people, a slightly decreasing trend can be noticed (Fig. 3). As knowledge

\section{Fig. 2: Employment in technology and knowledge-intensive sectors by sex}

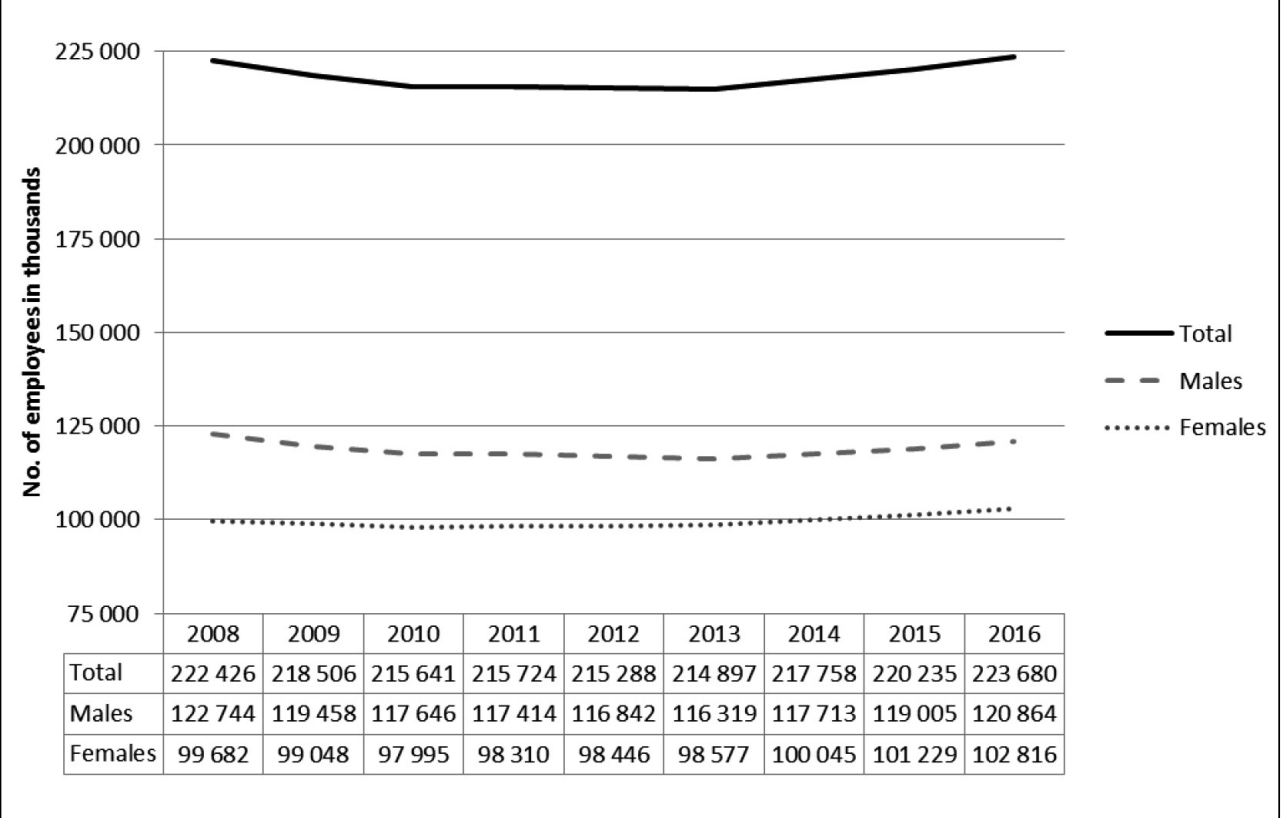




\section{Fig. 3: Employment in technology and knowledge-intensive sectors by education}

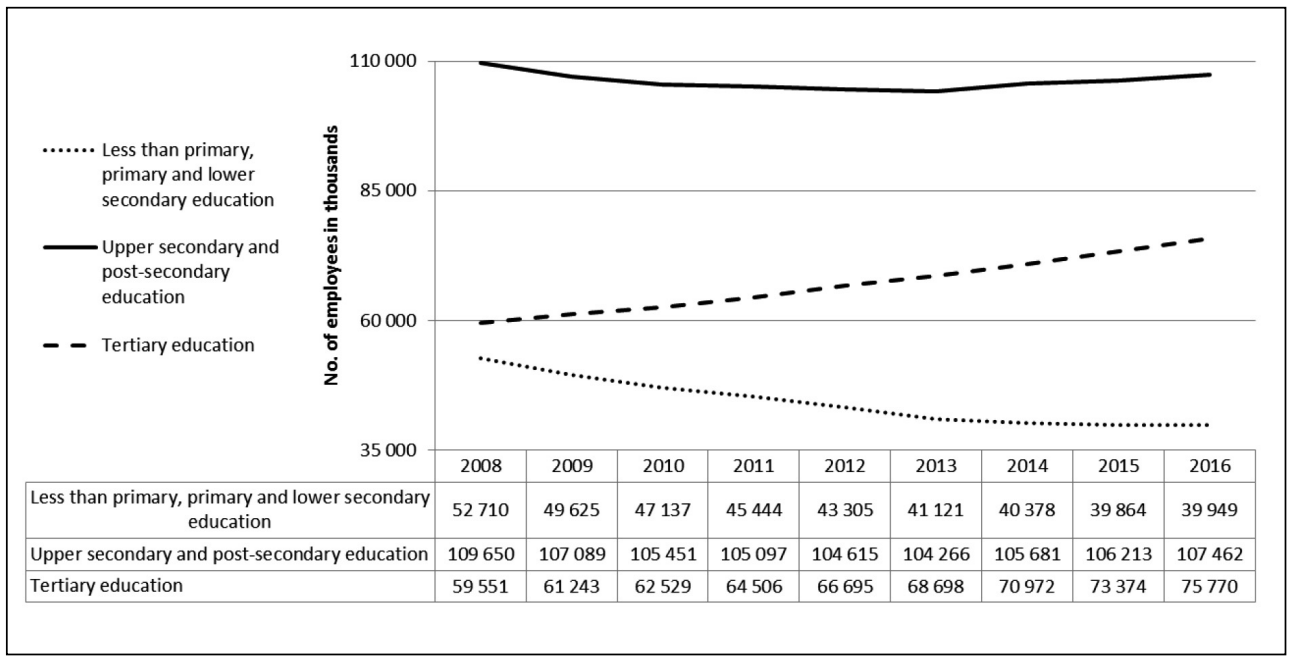

production is becoming increasingly important today, it encourages sustainable development also in the field of education. The ability to acquire, share, and use knowledge is critical for human capital development and it requires the transformation to our educational systems. Therefore, the presented approach to knowledge synergy calculation is usable also for educational purposes and human capital development in general.

Due to the facts explained above, the knowledge synergy evaluation becomes increasingly important also from the national and global viewpoint. It is the interest of each country to support knowledge sharing and increasing intellectual capital to reach a higher level of national competitiveness. Moreover, advanced knowledge sharing principles can consequently also be transformed into the educational system in order to increase national competitiveness. As Šegota, Tomljanovic and Hudek (2017) say, the modern business environment and international competitiveness are based on knowledge infrastructure hightech, and innovation. Results of their study showed that countries should consider the efficiency of exploitation of available resources including intellectual capital in order to increase the level of their competitiveness.
The above formula (10) was created with focus on its applicability in any industry or business area. It is a useful tool not only for measuring and improving intellectual capital of individual company, but also because of its versatility, as it can be used also for benchmarking purposes or other types of comparative statistics on both organizational and national level.

\section{Conclusions}

Scientific papers provide fragmented evaluations of knowledge synergy - they do not meet the needs of modern organisations that want to get a competitive advantage in knowledge management. To fill these research and knowledge gaps, this paper identifies knowledge synergy components (employee's knowledge and relations among employees), describes their content through their elements (types of relations and knowledge), and provides proposals for their evaluation.

Mathematical formulas are provided for the calculation of relations among employees based on their types. The proposed method for the evaluation of relations among employees assesses relations among employees, reveals specific features of cooperation, problem areas and knowledge sharing, which in turn allows 
for the adjustment of employees' performance, revision of the organisational structure of the organisation or its units and sound decisions on the improvement of employees' performance. To evaluate employee's knowledge - another component of synergy, factors should be grouped into two blocks: explicit knowledge and tacit knowledge. In case of each of these blocks, the proposed evaluation of employee's knowledge helps to analyse every factor, adjust the possibilities of knowledge acquisition, improvement of qualification, learning and career, as well as to evaluate employee's knowledge in a complex and objective manner. Thus, the calculation of knowledge synergy makes it possible to view, analyse and evaluate intermediate results.

The content of elements of a knowledge component - factors - must be normalised due to different units of measurement. In case of most knowledge component factors, the best value is the highest value, therefore factors should be maximised, i.e. minimising factors should be reduced to maximising factors. To normalise relations among employees, a construct is proposed - it helps calculate the value of knowledge synergy correctly. The proposed method allows for a quantitative evaluation of knowledge synergy in an organisation. Structural and dynamic evaluation of knowledge synergy enables an organisation to manage knowledge, thereby increasing its effectiveness.

\section{References}

Belohlavek, D. (2007). The Unicist Ontology of Intellectual Capital Building. Buenos Aires: Blue Eagle Group.

Bianchi, M. (2010). Perspectives for the extension of Graiciunas' span of control to the process of enterprise creation. Journal TILTAI Social Sciences, 53(4), 15-33.

Bivainis, J., \& Morkvėnas, R. (2008). Darbuotojų žinių potencialo vertinimas. Business: Theory and Practice, 9(2), 105-115. https://dx.doi.org/10.3846/16480627.2008.9.105-115.

Boyatzis, R. E. (1982). The Competent Manager: A Model for Effective Performance. New York: Wiley.

Brčić, Ž. J., \& Mihelič, K. K. (2015). Knowledge sharing between different generations of employees: an example from Slovenia. Economic Research, 28(1), 853-867.
https://dx.doi.org/10.1080/1331677X.2015. 1092308.

Cho, W., Shaw, M. J., \& Kwon, H. D. (2013). The effect of synergy enhancement on information technology portfolio selection. Information Technology and Management, 14(2), 125-142. https://dx.doi.org/10.1007/ s10799-012-0150-9.

Desauza, K. C. (2003). Knowledge Management Barriers - Why the Technology Imperative Seldom Works. Business Horizons, 46(1), 25-29. https://dx.doi.org/10.1016/S00076813(02)00276-8.

Dias, M. S. (2014). Gestão do conhecimento no setor público: identificando práticas e desafios no centro de desenvolvimento da tecnologia nuclear. Accounting and Management, 7(7), 193-208.

Drucker, P. (1980). Managing in Turbulent Times. New York: Harper \& Row.

Drucker, P., \& Peter, F. (1969). The Age of Discontinuity. Guidelines to Our Changing Society. New York: Harper \& Row.

Eikenberry, K. (2007). Remarkable Leadership: Unleashing Your Leadership Potential One Skill at a Time. San Francisco: Jossey-Bass.

EUROSTAT. (2017a). Annual data on employment in knowledge-intensive activities at the national level, by sex (from 2008 onwards, NACE Rev. 2). Retrieved July 3, 2017, from http://appsso.eurostat.ec.europa.eu/nui/show. do?dataset=htec_kia_emp2\&lang=en.

EUROSTAT. $(2017 \mathrm{~b})$. Employment in technology and knowledge-intensive sectors at the national level, by level of education (from 2008 onwards, NACE Rev. 2). Retrieved July 3, 2017, from http://appsso.eurostat. ec.europa.eu/nui/show.do?dataset=htec_emp_ nisced2\&lang=en.

Fink, K. (2005, June 29 - July 1). Knowledge Measurement and Interviewer Bias. Paper presented at I-KNOW '05, Graz, Austria. New York: ACM.

Fombelle, P. W., Jarvis, C. B., Ward, J., \& Ostrom, L. (2011). Leveraging customers' multiple identities: identity synergy as a driver of organizational identification. Journal of Academy of Marketing Science, 40(4), 587-604. https://dx.doi.org/10.1007/s11747-011-0254-5.

Ginevičius, R., \& Podvezko, V. (2007). Some problems of evaluating multicriteria decision methods. International Journal of Management and Decision Making, 8(5), 527-539. 
https://dx.doi.org/10.1504/IJMDM.2007. 013415.

Graičiūnas, V. A. (1937). Relationship in Organization. In L. H. Gulick \& L. F. Urwic (Eds.), Papers on the Science of Administration (182-187). N.Y.: I.P.A.

Haynes, K. S., \& Mickelson, J. S. (2009). Affecting Change: Social Workers in the Political Arena. New Jersey: Prentice Hall.

Helms, M., \& Cengage, G. (2006). Experience and Learning Curves. Encyclopedia of Management. Retrieved March 3, 2009, from http://www.enotes.com/managementencyclopedia.

Huang, Y., Ye, J., \& Gao, Z. (2012). Study on Team Stability Based on the Perspective of Knowledge Potential. iBusiness, 4(3), 256-259. https://dx.doi.org/10.4236/ib.2012.43032.

Hwang, C. L., \& Yoon, K. (1981). Multiple Attribute Decision-Making Methods and Applications. A State of the Art Survey. Berlin: Springer Verlag.

Jankauskienè, V., Kanapeckienè, V., Narkauskaitè, L., \& Valintëlienè, R. (2012). Visuomenès sveikatos priežiūros funkcijas vykdančių specialistų žinios ir igūdžiai. Visuomenès sveikata, 2(57), 45-56.

Juřičková, E. (2014, February 6 - February 7). Innovation's Dependence on Human Capital in the World's Most Innovative Countries. Paper presented at $2^{\text {nd }}$ International Conference on Innovation and Entrepreneurship (ICIE), Bangkok, Thailand. England, Sonning Common: ACPI.

Kaminskienè, L. (2011). Lietuvos kvalifikaciju sistemos ir europos kvalifikaciju sąrangos sąsajos. Kvalifikaciju ir profesinio mokymo plétros centras. Retrieved November 24, 2016, from http://www.kpmpc.It/LTKS_EKS/ LKA_tyrimas_LT.pdf.

Ketchen, D. J., \& Hult, G. T. M. (2011). Marketing and organization theory: opportunities for synergy. Journal of the Academy of Marketing Science, 39(4), 481-483. https://dx.doi.org/10.1007/s11747-011-0259-0.

Khan, I. A. (2010). Knowledge Groups: A Model for Creating Synergy across the Public Sector. Public Organization Review, 10(2), 139-152. https://dx.doi.org/10.1007/s11115009-0101-z.

Klafke, R. V., Lievore, C., Picinin, C. T., de Francisco, A. C., \& Pilatti, L. A. (2016). Primary knowledge management practices applied in Brazil, Russia, India and China
(BRIC) industries from 2001-2010. Journal of Knowledge Management, 20(4), 812-828. https://dx.doi.org/10.1108/JKM-12-2015-0522.

Kloudová, J., \& Chwaszcz, O. (2011). New Way of Analysis of Creative Centers within Europe. Economics \& Management, 16, 197-206.

Lobanova, L., \& Chlivickas, E. (2009). Žmogiškuju išteklių kompetencijų vertinimas viešajame sektoriuje. Viešasis administravimas, 21(1), 63-72.

Matošková, J. (2016). Measuring Knowledge. Journal of Competitiveness, 8(4), 5-29. https://dx.doi.org/10.7441/joc.2016.04.01.

Meenu, D., Mikku, D., \& Shishodia, Y. S. (2012). Knowledge Management and Organizational Competencies: A Harmonic Collaboration. International Journal of Advanced Research in Computer Science and Software Engineering, 2(12), 45-50.

Moradmand, N., Datta, A., \& Oakley, G. (2014, June 23 - June 27). An Interactive Multimedia Development Life Cycle Model Based on a Cognitive Theory of Multimedia Learning. Paper presented at World Conference on Educational Media and Technology 2014, Tamplere, Finland. USA, Waynesville: Association for the Advancement of Computing in Education (AACE).

Morkvènas, R. (2010). Organizacijos žiniu potencialo vertinimas. Daktaro disertacija. Vilnius: Technika.

Neef, D., Siesfeld, T., \& Cofela, J. (1998). The Economic Impact of Knowledge. Boston: Butterworth-Heinemann.

Newman, M., Barabási, A., \& Duncan, J. W. (2006). The Structure and Dynamics of Networks. New York: Princeton.

Nonaka, I., \& Takeuchi, H. (1995). The Knowledge-creating Company. Oxford: Oxford University Press.

Opricovic, S., \& Tzeng, G.-H. (2004). Compromise solution by MCDM methods: A comparative analysis of VIKOR and TOPSIS. European Journal of Operational Research, 156(2), 445-455. https://dx.doi.org/10.1016/ S0377-2217(03)00020-1.

Park, M., Lee, H.-S., \& Kwon, S. (2010). Construction knowledge evaluation using expert index. Journal of Civil Engineering and Management, 16(3), 401-411. https://dx.doi. org/10.3846/jcem.2010.46.

Podvezko, V. (2008). Sudètingų dydžių kompleksinis vertinimas. Verslas: Teorija ir 
praktika. Business: Theory and Practice, 9(3), 160-168. https://dx.doi.org/10.3846/16480627.2008.9.160-168.

Sala-i-Martin, X., Bilbao-Osorio, B., Blanke, J., Drzeniek Hanouz, M., \& Geiger, T. (2011, January 28). The Global Competitiveness Index 2011-2012: Setting the Foundations for Strong Productivity. Paper presented at World Economic Forum 2011, Davos, Switzerland. Geneva: WEF.

Senge, P. M. (2006). The fifth discipline: The art and practice of the learning organization. New York: Doubleday / Currency.

Simon, H. A. (1947). Administrative Behavior: a Study of Decision-Making Processes in Administrative Organizations. New York: Simon \& Schuster.

Skačkauskienè, I., \& Katinienè, A. (2015). Žiniu potencialo sampratos formavimasis tinklaveikos visuomenèje. Mokslas Lietuvos ateitis, 7(2), 163-171. https://dx.doi. org/10.3846/mla.2015.740.

Skačkauskienè, I., Kazlauskienè, E., \& Katinienè, A. (2017). Modelling Knowledge Synergy Evaluation. Montenegrian Journal of Economic, 13(1), 35-49. https://dx.doi. org/10.14254/1800-5845/2017.13-1.2.

Smith, I. W. (2004). Continuing Professional Development and Workplace Learning 7: Human Resource Development - a Tool for Achieving Organizational Change. Library Management, 25(3), 148-151. https://dx.doi. org/10.1108/01435120410522370.

Smith, R. (2001). Knowledge Management The Road Ahead. Presented at the 2nd Conference \& Expo of the Staff Exchange Program of The World Bank Group, Washington, D.C., USA. Available from http://www.reidgsmith.com/Power.htm.

Smith, R., \& Farquhar, A. (2000). The Road Ahead for Knowledge Management: An Al Perspective. Al Magazine, 21(4), 17-40.

Steiner, I. (1972). Group Process and Productivity. New York: Academic Press.

Strassmann, P. (1998). The Value of Knowledge Capital. American Programmer, 11(3), 3-10.

Šegota, A., Tomljanovic, M., \& Hudek, I. (2017). Contemporary approaches to measuring competitiveness - the case of EU member states. Proceedings of Rijeka Faculty of Economics: Journal of Economics and Business, 35(1), 123-150. https://dx.doi. org/10.18045/zbefri.2017.1.123.

Torres, A. A. L., Ziviani, F., \& Silva, S. M. (2012). Mapeamento de competências: ferramenta para a comunicação e a divulgação científica. Transinformação, 24(3), 191-205.

Urban, B., \& Joubert, G. C. D. S. (2017). Multidimensional and comparative study on intellectual capital and organisational performance. Journal of Business Economics and Management, 18(1), 84-99. https://dx.doi. org/10.3846/16111699.2016.1255990.

Urwick, L. (1943). Personnel Management in Relation to Factory Organization. London: Urwick Institute of Labour Management.

Ustinovichius, L., \& Zavadskas, E. K. (2004). Statybos investiciju efektyvumo sistemotechninis ivertinimas. Vilnius: Technika.

Vanagas, R., \& Tumènas, A. (2008). Savivaldybès darbuotoju tarnybinès veiklos vertinimas veiklos valdymo kontekste. Viešoji politika ir administravimas, 25, 57-67.

Wu, W.-P., \& Choi, W. L. (2004). Transaction Cost, Social Capital and Firms' Synergy Creation in Chinese Business Networks: An Integrative Approach. Asia Pacific Journal of Management, 21(3), 325-343. https://dx.doi. org/10.1023/B:APJM.0000036466.90433.92.

Žaptorius, J. (2007). Darbuotoju motyvavimo sistemos kūrimas ir jos teorinè analizè. Socialogija, 18(4), 105-117.

Prof. dr. Ilona Skačkauskienè

Vilnius Gediminas Technical University

Faculty of Business Management

Department of Management

Lithuania

ilona.skackauskiene@vgtu.It

Ing. Denisa Hrušecká, Ph.D.

Tomas Bata University in Zlín

Faculty of Management and Economics

Department of Industrial Engineering and Information Systems

Czech republic

hrusecka@fame.utb.cz

Aušra Katinienè

Vilnius Gediminas Technical University

Faculty of Business Management

Department of Management

Lithuania

ausra.katiniene@vgtu.It

Dr. Martin Čepel, Ph.D., MBA

LIGS University LLC

USA

cepel@benzinol.com 


\section{Abstract}

\section{EVALUATION OF KNOWLEDGE SYNERGY COMPONENTS}

\section{Ilona Skačkauskienè, Denisa Hrušecká, Aušra Katinienè, Martin Čepel}

There is no doubt that knowledge is a key asset of any organisation, enabling it to get a competitive advantage, implement innovation, deal with difficulties and improve its management processes. Requirements on employees' knowledge have been rising in recent years, especially with regard to the new trends and currently the widely discussed fourth industrial revolution. In the emerging network economy and knowledge society, organisations must be ready for complex knowledge dissemination and management processes. Knowledge is collected, stored, assessed, and created by an organisation and shared by its members. In the course of knowledge dissemination, members of the organisation create synergy which generates unique knowledge. Managing organisational knowledge necessary for the creation of added value and the acquisition of a competitive advantage requires evaluating the knowledge synergy and its components. The paper aims at identifying knowledge synergy components and providing an evaluation method of employees' knowledge synergy and its components to have a rational and objective evaluation of employees' knowledge, relations among employees, and organisational knowledge synergy. To achieve this aim, knowledge synergy components are identified, evaluation issues are revealed, types of knowledge synergy relations are presented together with an evaluation formula for each of these relations, components of employees' knowledge and factors reflecting knowledge content are specified, an evaluation formula for each component is provided, and an organisational knowledge synergy evaluation method is described. Due to its versatility, presented results are applicable in any industry or business area for measuring and improving intellectual capital as well as for benchmarking purposes. The research applies methods of analysis, synthesis, graph theory and combinatorics as well as a systematic approach.

Key Words: Knowledge management, knowledge synergy, knowledge sharing, intellectual capital, evaluation, communication.

JEL Classification: M1.

DOI: 10.15240/tul/001/2018-1-010 